\title{
Penerapan Camels pada Bank Konvensional yang Listed di BEI
}

\author{
Imam Abrori ${ }^{1}$, Abdurrahim ${ }^{2}$ \\ Program Studi Manajemen, STIE WIdya Gama Lumajang ${ }^{1}$ \\ Fakultas Ekonomi / Prodi Managemen, Universitas Muhammadiyah Jember ${ }^{2}$ \\ Email: ari.abrorii@gmail.com
}

\begin{abstract}
Abstrak
Penelitian ini dilakukan untuk menguji pengaruh Capital Adequacy Ratio (CAR), Biaya Operasional Terhadapa Pendapatan Operasional (BOPO), Non Performing Loan (NPL), Net Interest Margin (NPL) dan Loan To Deposi Ratio (LDR) terhadap Profitabilitas Perbankan (ROA). Populasi yang menjadi obyek dalam penelitian ini adalah bank konvensional yang listed di Bursa Efek Indonesia. Jumlah sample yang digunakan adalah 9 bank konvensional yang listed di Bursa Efek Indonesia. Metode yang digunakan dalam penelitian ini adalah dengan menggunakan analisis regresi berganda dengan uji hipotesis yaitu uji t. Sebelum menggunakan analisis regresi berganda, dilakukan uji asumsi klasik terlebih dahulu. Hasil uji hipotesis secara parsial (uji t) pada bank konvensional menunjukkan bahwa variabel CAR tidak berpengaruh dan tidak signifikan terhadap profitabilitas perbankan (ROA). Variabel BOPO dan LDR berpengaruh negatif dan signifikan terhadap profitabilitas perbankan (ROA), sedangkan variabel NPL dan NIM berpengaruh positif dan signifikan terhadap profitabilitas perbankan (ROA). Kemampuan variabel independen mempengaruhi tingkat profitabilitas bank sebesar 64\% sedangkan sisanya dipengaruhi variabel lain yang tidak dimasukan ke dalam model penelitian.
\end{abstract}

\section{Kata kunci: CAR, BOPO, NPL, LDR dan ROA.}

\begin{abstract}
This study was conducted to examine the influence of Capital Adequacy Ratio (CAR), Biaya Operasional Terhadap Pendapatan Operasional (BOPO), Non Performing Loan (NPL), Net Interest Margin (NPL) and loan to deposi Ratio (LDR) to the Banking Profitability (ROA). Populations that are objects of this study are conventional banks listed on the Indonesia Stock Exchange. The method used in this research is to use multiple regression analysis to test the hypothesis that the $t$ test. Before using multiple regression analysis, performed classical assumption beforehand. From the results of partial hypothesis test ( $t$ test) in conventional banks showed that the CAR variable has no effect and no significant effect on bank profitability (ROA). Variable ROA and LDR significant negative effect on bank profitability (ROA), while variable NIM and NPL positive and significant impact on banking profitability (ROA). The ability of the independent variables affect the profitability of banks by $64 \%$ while the rest influence other variables not included in the research model.
\end{abstract}

Keywords: CAR, BOPO, NPL, LDR and ROA. 


\section{PENDAHULUAN}

Krisis ekonomi global dipicu oleh kasus subprime montgage di Amerika Serikat 2007 jauh lebih parah dari krisis sebelumnya. Bahkan krisis kali ini telah menyentuh sendi-sendi sistem kapatalisme global. Selain itu, lembaga-lembaga keuangan internasional maupun negara maju dan negara berkembang juga ditentukan melakukan penataan ulang system keuangan global dan nasional agar lebih tahan menghadapi gejolak (Kadin Indonesia, 2014). Dalam proses pemulihan ekonomi global, akan berdampak positif pada peningkatan perdagangan dunia dan di dalam peningkatan itu terlihat kecenderungan yang lebih cepat akan terjadi dikawasan Asia. Asia diperkirakan akan memperoleh manfaat positif yang berarti dengan pemulihan ekonomi tersebut. Dalam proses pemulihan dan dalam tahun-tahun sesudahnya dapat diperkirakan bahwa Indonesia akan lebih menarik sebagai tempat investasi oleh investor asing karena tingkat konsumsi dan kelas menengah yang tumbuh sekaligus menjadi pasar yang menarik di Asia (Kadin Indonesia, 2014). Salah satu tujuan utama investasi untuk mendapatkan keuntungan atas pengorbanan yang dilakukan oleh investor.

Pasar modal secara umum merupakan tempat bertemunya para penjual dan pembeli untuk melakukan transaksi dalam rangka berinvestasi dan memperoleh modal (Kasmir, 2012; 184). Sejalan pemuliahan ekonomi dunia tingkat investasi di pasar modal indonesia terus meningkat, dilihat dari laporan OJK 2015, Indek harga saham di Indonesia berdasarkan perkembangan IHSG dan nilai perdagangan saham harian periode 2005- 2015* menunjukan fluktuatif harga kearah positif setiap tahunnya. Tahun 2005 dan 2006 IHSG pada posisi yang rendah, tetapi pergolakan ekonomi dunia tidak berpengaruh signifikan terhadap indek saham indonesia ditunjukan dengan indek tahun 2007 hingga 2015 IHSG terus menunjukan peningkatan yang positif dan pada triwulan 12015 meningkat 5,6\% jika dibandingkan pada posisi akhir triwulan IV 2014, (tabel 1.1), tentu ini merupakan awal yang positif untuk tahun 2015 .

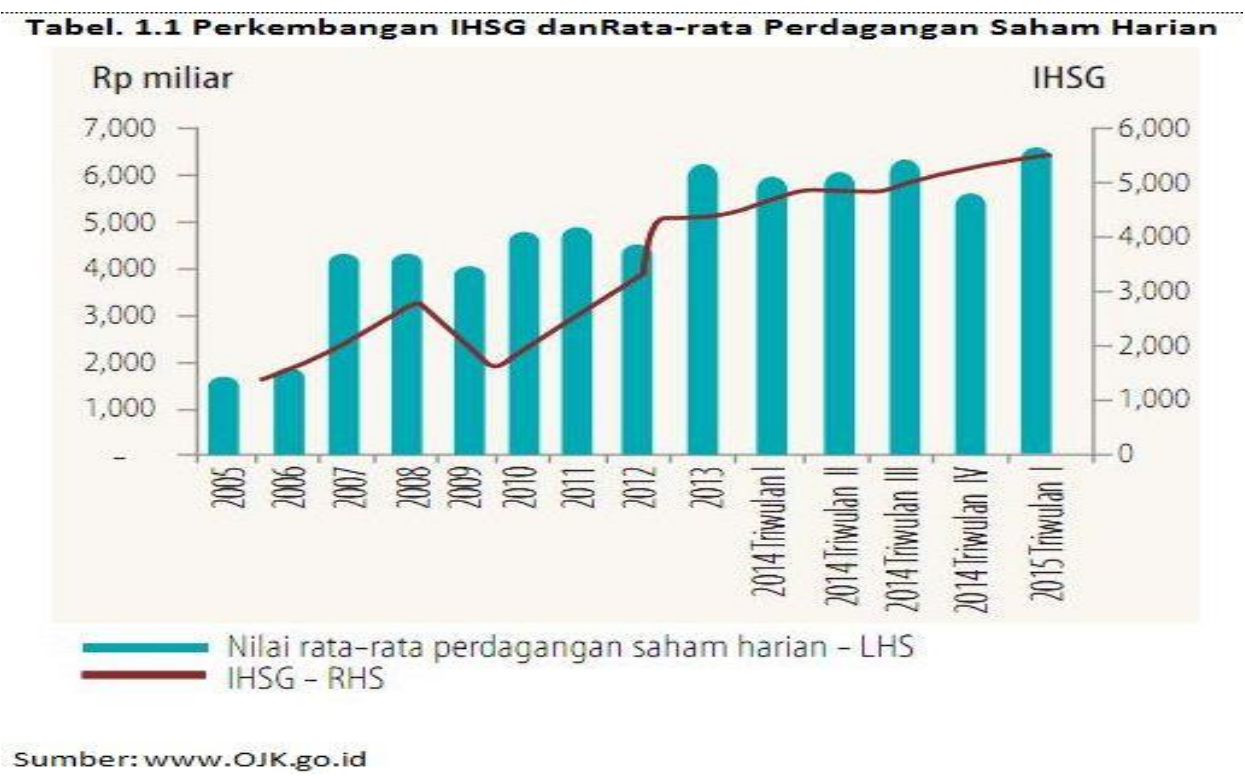

Meningkatnya harga saham dan transaksi investor terhadap Pasar Modal Indonesia belum tentu mempengaruhi perusahaan go public secara interen, seperti yang terjadi pada perushaan perbankan go public pada tahun 2014, terutama pada bank konvesional yang terdaftar di BEI 40 bank di bandingkan dengan bank syariah 1 bank. Berdasarkan meningkatnya IHSG bank konvensional lebih mudah mendapat modal di bandingkan bank syariah, namun dalam 
peluang ini bank konvesional mengalami penurunan pertumbuhan yang disebabkan meningkatnya BI rate ditunjukan pada tabel 1.3, ditandai dengan menurunnya aset bank konvensional, penghimpunan dana dan penyaluran dana dibandingkan triwulan sebelumnya masing-masing sebesar $-1,33 \%,-1,98 \%$ dan $-0,79 \%$. DPK dan kredit industri perbankan juga mengalami penurunan apabila dibandingkan dengan tahun sebelumnya, dari masing- masing sebesar $16,8 \%, 16,4 \%$ dan $22,3 \%$ menjadi $15,4 \%, 13,8 \%$ dan $15,1 \%$, ROA mengalami penurunana sebesar $2,8 \%$ dari tahun sebelumnya, CAR dan rasio NPL gross menunjukan kinerja yang positif, yakni sebesar 19,8\% dan 1,9\%. Selain itu pencadangan yang dilakukan oleh perbankan juga cukup memadai, sehingga NPL net berada pada tingkat yang rendah yaitu tetap sebesar 0,9\% pada akhir triwulan I-2014, seperti halnya pada triwulan IV-2013.

Tabel. 1.3 Kondisi Umum Perbankan Konvensional

\begin{tabular}{|c|c|c|c|c|c|c|c|c|c|c|}
\hline \multirow{2}{*}{$\begin{array}{l}\text { Indikator } \\
\text { Utama }\end{array}$} & \multirow{2}{*}{ Satuan } & \multicolumn{2}{|c|}{2012} & \multicolumn{4}{|c|}{2013} & \multicolumn{3}{|c|}{2014} \\
\hline & & TW III & TW IV & TWI & TW II & TW III & TW IV & Jan & Feb & TWI \\
\hline Total Aset & $(T R p)$ & $3.945,4$ & $4.131,6$ & $4.254,0$ & $4.416,1$ & $4.501,7$ & $4.654,2$ & 4880,4 & $4.888,7$ & $4.884,6$ \\
\hline DPK & (T Rp) & 2990,5 & $3,142,1$ & $3.218,3$ & $3,341,2$ & $3.408,5$ & $3.436,4$ & 3.594 .7 & $3.603,6$ & 3.599 .2 \\
\hline Kredit & (T Rp) & $2.512,2$ & $2.653,0$ & 2740,9 & 2.912 .1 & $3.059,3$ & $3.247,9$ & $2.184,3$ & $2.203,0$ & $2.193,7$ \\
\hline LDR & (\%) & 83,8 & 84,1 & 84,7 & 86,5 & 88,9 & 89,7 & 90,6 & 90,5 & 90,5 \\
\hline NPLS Gros & (\%) & 2,2 & 2,0 & 2,0 & 2,0 & 1,9 & 1,8 & 1,84 & 1,94 & 1,9 \\
\hline NPLs Net & (\%) & 0,99 & 0.93 & 1,0 & 0,8 & 0,6 & 0,9 & 0,90 & 0,98 & 0,9 \\
\hline CAR & (\%) & 17,3 & 17,4 & 19,1 & 18,3 & 18,0 & 18,5 & 19,76 & 19,85 & 19,8 \\
\hline NIM & (96) & 5,43 & 5,50 & 5,4 & 5,4 & 5,5 & 5,1 & 4,17 & 4,18 & 4,2 \\
\hline ROA & (96) & 3,10 & 3,10 & 3,0 & 3,0 & 3,0 & 3,5 & 2,89 & 2,79 & 2.8 \\
\hline
\end{tabular}

Sumber- sistem informasi perbankan Bank Indonesia

BI rate merupakan kebijakan moneter berupa suku bunga acuan pada bank. Tingkat suku bunga bank merupakan harga yang harus dibayarkan kepada nasabah dan yang harus dibayar oleh nasabah kepada bank (Kasmir, 2012; 114). Perubahan tingkat suka bunga akan mempengaruhi deposito berjangka, tabungan dan suku bunga pinjamam (BI).

Menurunyan tingkat profitabilitas yang di lihat dari return on asset (ROA) pada tahun 2014 sampai, menjadi fenomena yang menarik untuk diteliti. Profitabilitas merupakan kemampuan perusahaan dalam memperoleh laba dengan hubungan penjulaalan, total aktiva dan mopdal sendiri Agus (2001: 122). Tingkat profitabilitas ini diukur dengan menggunakan rasio keuangan return on asset (ROA) karena ROA lebih memfokuskan pada kemampuan perusahaan untuk memperoleh earning dalam operasi perusahaan secara keseluruhan. Selain itu juga, dalam penentuan tingkat kesehatan suatu bank, Bank Indonesia (BI) lebih mementingkan penilaian ROA dari pada ROE karena Bank Indonesia (BI) lebih mengutamakan nilai profitabilitas suatu bank yang diukur dengan asset yang dananya bank sebagian besar berasal dari dana simpanan masyarakat sehingga ROA lebih mewakili dalam mengukur tingkat profitabilitas perbankan (Dendawijaya, 2001 dalam skripsi Fitriani, 2010). Return on asset (ROA) merupakan kemampuan manajemen perusahaan dalam menghasilkan income dari pengelolaan aset perusahaan yang dimilikinya (Farah, 2005; 60).

Dalam perusahaan perbankan untuk melihat kondisi keuangannya, menggunakan rasio keuangan bank yaitu rasio CAMELS (SE BI No.3/30/DPNP tanggal 14 Desember 2001). Menurut Kasmir $(2012$; 44) rasio CAMELS merupakan rasio untuk menentukan tingkan kesehatan bank. Dalam menilai tingakat kesehatan bank rasio CAMELS (Capital, Assets, Managemet, Earning, Liquidity). Rasio CAMEL meliputi aspek capital meliputi capital 
adequacy ratio (CAR), aspek aset meliputi non performing loan (NPL), aspek earning meliputi return on asset (ROA) dan biaya operasional dan pendapatan operasioanl (BOPO), net interest margin (NIM), aspek likuiditas meliputi load to deposits ratio (LDR), (Kasmir, 2012; 44). Rasio CAMEL merupakan rasio yang digunakan untuk menganalisi kesehatan perbankkan ditunjukan dari laporan OJK dan statistik lembaga keuangan. Rasio tersebut juga digunakan sebagia prediksi kinerja keuangan perbankkan dilakukan oleh Nurani (2012) dengan hasil penelitian menunjukan variabel CAR, BOPO berpengaruh negatife terhadap ROA dan LDR dan NPL berpengaruh positif terhadap ROA .

Penelitian ini akan melakukan penegembangan dari penelitian sebelumnya dengan penambahan variabel bebas, yaitu : Capital Adequacy Ratio (CAR) adalah rasio kinerja bank untuk mengukur kecukupan modal yang dimiliki bank untuk menunjang aktiva yang mengandung atau menghasilkan risiko, misalnya kredit yang diberikan (Farah, 2005:63). Semakin tinggi rasio CAR akan semakin baik posisi modal (Margareta dan Masheilly, 2013). Rasio keuangan yang digunakan sebagai proksi terhadap nilai suatu resiko kredit adalah Non Performing Loan (NPL). Menurut Hariyani (2010:53) rasio NPL (Non Peformoing Loan) atau rasio kredit bermasalah. Rasio ini menunjukan kemampuan managemen bank dalam menengelola kredit bermasalah yang diberikan oleh bank. Semakin tinggi rasio ini maka akan semakin buruk kualitas kredit kredit sehingga kondisi bermasalah bank semakin tinggi dan akan mempengaruhi penadapatan bank (Eng, 2013). Menurut Hariyani (2010:54) rasio BOPO (biaya opersional terhadap pendapatan operasional) atau disebut rasio efisiensi ini digunakan untuk mengukur kemampuan managemen bank dalam mengendalikan biaya operasional terhadapa pendapatan operasional. Semakin efisien BOPO makan semakin baik pendapatan bank (Eng, 2013). Menurut Hariyani (2010:54) net income margin (NIM) merupakan rasio yang menunjukkan kemampuan manajemen bank dalam mengelola aktiva produktifnya untuk menghasilkan pendapatan bunga bersih. Semakin tinggi NIM maka semakin baik pendapatan bank (Aini, 2013). Menurut Hariyani (2010:55) LDR (Loan To Deposit Ratio) atau rasio kredit terhadap deposito/simpanan. Rasio ini digunakan untuk menilai likuiditas suatu bank dengan cara membagi jumlah kredit yang diberikan oleh bank terhadap dana pihak ketiga. Semakin tinggi LDR makin baik tingkat kredit yang diberikan dan akan meningkatkan laba bank (Nyoman dan Erni, 2015).

Berdasarkan laporan OJK 2014 dan 2015 bank konvesional mengalami fluktuatif pada setiap rasionya. Rasio keuangan bank tersebut digunakan sebagai variabel penelitian. Perbedaan penelitian ini dengan penelitian terdahulu adalah penelitian ini menggunkan data perusahaan bank konvensional yang terdaftar di BEI periode 2010-2014. Penelitian ini bertujuan untuk meneliti kembali dengan menggunkan pengukuran terhadap profitabilitas. Profitabilitas merupakan kemampuan perusahaan untuk menghasilkan laba selama periode tertentu Brigham dan Houston (2006; 107). Rasio profitabilitas diperoksikan oleh rasio return on asset (ROA) dengan waktu penelitian 2010-2014. Peneliti bertujuan untuk menguji apakah terjadi penguatan konsistensi terhadap teori maupun penelitian yang telah ada atau sebaliknya.

\section{METODE PENELITIAN}

Obyek penelitian adalah perbankan konvesional yang listed di BEI periode 2010-2014. Finansial rasio merupakan rasio yang digunakan untuk menganalisa laporan keuangan perusahaan dan CAMELS merupakan metode untuk mengtahui tingkat kesehatan Bank menggunakan rasio. Variabel yang digunakan dalam penelitian ini adalah rasio CAMELS yaitu; Capital Aquancy Ratio (CAR), Non Performing Load (NPL), Biaya Operasional 
Terhadap Pendapatan Opersional (BOPO), Net Interest Margin (NIM), dan Load To Deposit Ratio (LDR) sebagai vaiabel (X) sedangkan profitabilitas menggunkan rasio Retur On Assets (ROA) sebagai variabel (Y). Penelitian ini, untuk mengetahui pengaruh variabel independen terhadap variabel dependen dengan alat uji hipotesis menggunakan uji t (parsial).

Populasi yang digunakan dalam penelitian ini adalah perusahaan perbankan konvensional yang tercatat di Bursa Efek Indonesia (2010-2014) yaitu 40 Bank. Teknik pentuan sampel menggunkan pourposive sampling dari seluruh perusahaan perbankan yang listed di BEI dengan kriteria sebagai berikut: a. Penerbit IPO perbankan konvesional sebelum tahun 2011 di BEI. b. Perusahaan perbankan konvensional yang listed di BEI yang mempublikasikan laporan keuangan dan telah di audit selama periode penelitian. c. Perusahaan perbankan konvensional yang listed di BEI dan membagikan deviden selama periode penelitian. Berdasrakan kriteria di atas sampel dalam penelitian ini adalah 9 perusahaan perbankan.

\section{HASIL DAN PEMBAHASAN}

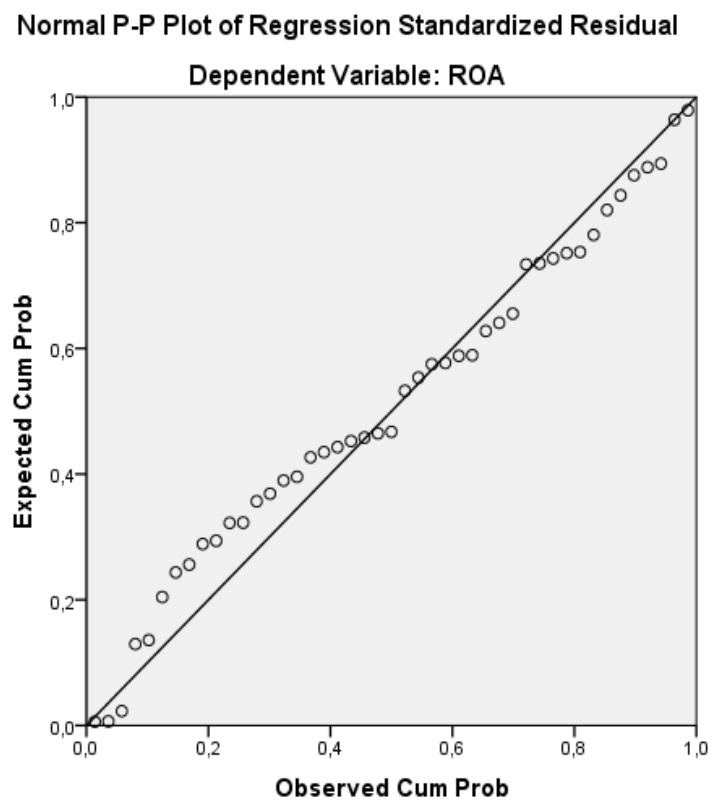

Gambar. 4.1

Sumber: output spss

Berdasarkan gambar 4.1 terlihat bahwa pola menunjukan distribusi normal, karena data mengikuti garis arah garis grafik histogramnya. Dari gambar 4.2 normal P-Plot menunjukan bahwa data menyebar di sekitar garis diagonal dan mengikuti arah garis diagonalnya, sehingga dapat disimpulkan bahwa asumsi normalitas terpenuhi.

Uji asumsi klasik dalam penelitian ini terdiri dari: Uji Autokorelasi, Multikolonieritas, dan Heterokedastisitas. Keseluruhan uji menggunkan program SPSSv for windows.

Tabel. 4.1 Hasil Uji Autokorelasi

Durbin Watson

\begin{tabular}{|c|c|}
\hline Model & DW \\
\hline 1 & 1,467 \\
\hline
\end{tabular}

Sumber: Lampiran 3 
Dari tabel di 4.1 bahwa nilai DW= 1,467 selanjutnya akan dibandingkan dengan nilai tabel signifikan 0,05, dengan jumlah sampel $\mathrm{N}=45$ dan variabel independen $5(\mathrm{k}=5)$ dapat diketahui nilai $\mathrm{dL}=1,2176$ dan $\mathrm{dU}=1,7886$. Dari asumsi perbandingan jika DW terletak antara dU dan $\mathrm{dL}$, maka uji tersebut tidak dapat disimpulkan.

Tabel. 4.2 Hasil Uji Multikolinearitas

\begin{tabular}{l|lll|ll|l}
\hline Model & \multicolumn{2}{|c|}{ Tolerance } & \multicolumn{2}{c|}{ VIF } & Keterangan \\
\hline CAR & 0,875 & $\geq 0,1$ & $1,143 \leq 10$ & Non Multikolinieritas \\
\hline BOPO & 0,828 & $\geq 0,1$ & 1,208 & $\leq 10$ & Non Multikolinieritas \\
\hline NPL & 0,836 & $\geq 0,1$ & 1,196 & $\leq 10$ & Non Multikolinieritas \\
\hline NIM & 0,673 & $\geq 0,1$ & 1,487 & $\leq 10$ & Non Multikolinieritas \\
\hline LDR & 0,628 & $\geq 0,1$ & 1,592 & $\leq 10$ & Non Multikolinieritas \\
\hline
\end{tabular}

Sumber: Lampiran 3

Dari table 4.2 nilai tolerance lebih dari 0,1 dan nilai VIF kurang dari 10 maka data tersebut dinyatakan tidak terjadi multikolineritas.

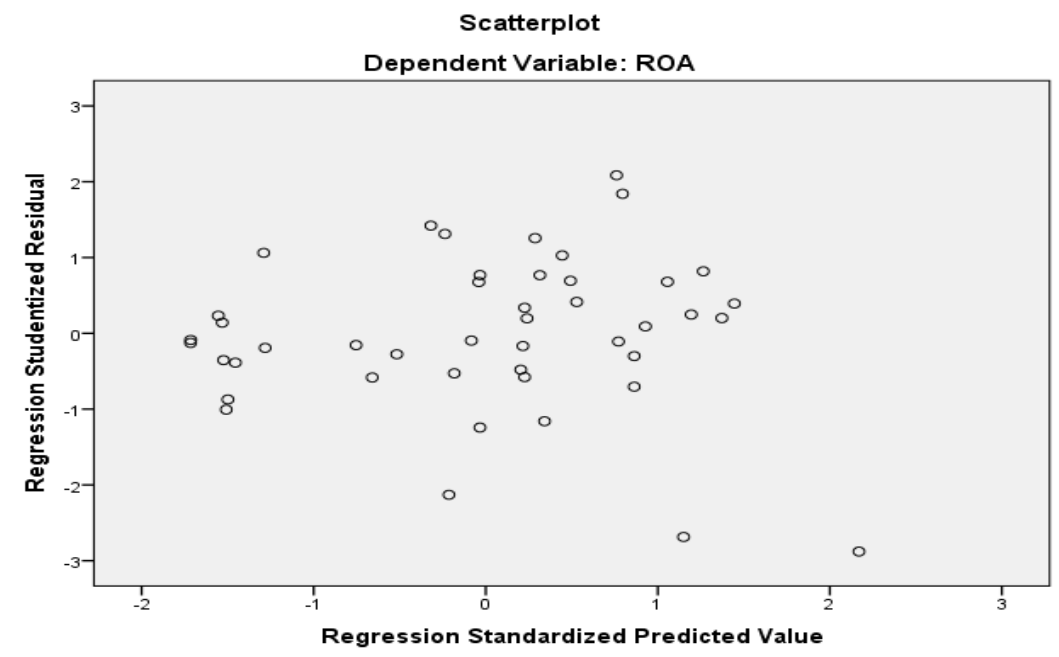

Gambar. 4.3 Heteroskadesitas

Sumber: output spss

Dari gambar 4.3 tidak menunjukan pola atau bentuk tertentu, tampak titik menyebar secara acak serta menyebar secara marata diatas 0 maupun dibawah 0 , maka dapat disimpulkan bahwa tidak terjadi heterodastisitas padal model regresi yang digunakan.

Tabel 4.3

Hasil Uji Koefisien Determinasi

\begin{tabular}{|l|c|r|r|}
\hline model & R & R Square & Adjusted R Square \\
\hline 1 & 0,804 & 0,647 & 0,602 \\
\hline
\end{tabular}

Sumber: Lampiran 3

Dari tabel 4.4 dapat diperoleh nilai $\mathrm{R}$ Square $\left(\mathrm{R}^{2}\right)$ sebesar 0,64 , berarti nilai $\mathrm{R}^{2}$ mendekati nilai 1, maka dapat disimpulkan semakin kuat kemampuan variabel bebeas menerangkan variabel terikat dan dapat diartikan variasi perubahan variable Return On Asset bank konvensional dapat dijelaskan dan dipengaruhi oleh variabel Capital Adequacy Ratio (X1), Biaya Operasional Terhadapa Pendapatan Operasional (X2), Non Performing Loan (X3), Net 
Interest Margin (X4) dan Loan to Deposit Ratio (X5) sebesar 64\% sedangkan sisanya sebesar $36 \%$ dijelaskan variabel lain diluar model penelitian ini yaitu faktor eksternal seperti inflasi, $\mathrm{BI}$ rate, kurs, dan kebijkan pemerintah.

Tabel. 4.4

Hasil Uji t

\begin{tabular}{|l|c|r|r|}
\hline Model & B & T & \multicolumn{1}{c|}{ sig. } \\
\hline Constant & 4,99 & 5,135 & 000 \\
\hline CAR & 0,003 & 0,156 & 0,877 \\
\hline BOPO & $-0,027$ & $-3,544$ & 0,001 \\
\hline NPL & 0,187 & 2,689 & 0,01 \\
\hline NIM & 0,036 & 3,192 & 0,003 \\
\hline LDR & $-0,026$ & $-2,259$ & 0,03 \\
\hline
\end{tabular}

Sumber: Lampiran 3

\section{Pengaruh capital adequacy ratio terhadap return on asset}

Penelitian yang dilakukan menunjukkan, bahwa nilai koefisien variabel capital adequacy ratio sebesar 0,003 dengan arah positif dan hasil pengujian hipotesis telah membuktikan pengaruh capital adequacy ratio terhadap return on asset memiliki nilai $t_{\text {hitung }} 0,156 \leq 1,683$ dan signifikan $0,887 \geq 0,05$, maka Ho diterima dan Ha ditolak, yang berarti secara persial variabel capital adequacy ratio tidak berpengaruh positif dan tidak signifikan terhadap return on asset pada bank konvensional yanng listing di Bursa Efek Indonesia. Dapat disimpulkan semkain tinggi nilai CAR makan tidak akan mempengaruhi tingkat profitabilitas bank konvesional.

Hasil penelitian tidak sejalan dengan kajia teori yang dikemukakan oleh Farah (2005:63), bahwa capital adequacy ratio adalah rasio kinerja bank untuk mengukur kecukupan modal yang dimiliki bank untuk menunjang aktiva yang mengandung atau menghasilkan risiko. Semakin besar rasio CAR menujukan kemampuan bank dalam mengendalikan resiko dan dapat mempengaruhi profitabilitas, sehingga kondisi bermasalah bank semakin kecil.

Hasil hipotesis penelitian menyatakan CAR tidak berpengaruh dan tidak signifikan terhadap ROA. Hipotesis tidak mendukung penelitian sebelumnya yang dilakukan oleh Margareta (2013) menunjukkan hasil bahwa Capital Adequacy Ratio (CAR) berpengaruh positif dan signifikan terhadap Return On Asset (ROA). Perbedan ini dikarenakan periode penilitian berbeda dan sampel yang digunakan berbeda. Peneliti menggunkan periode 2010-2014 sedangkan Margareta periode 2007-2011 dan sampel yang digunkan peneliti 9 bank sedangkan penelitian terdahulu 31 bank.

Pengaruh biaya operasional terhadap pendapatan operasional terhadap return on aset Penelitian yang dilakukan menunjukkan, bahwa nilai koefisien variabel biaya operasional terhadap pendapatan operasional sebesar -0,027 dengan arah negatif dan hasil pengujian hipotesis telah membuktikan pengaruh biaya operasional terhadap pendapatan operasional terhadap return on asset memiliki nilai $t_{\text {hitung }}-3,544 \geq-1,683$ dan signifikan $0,001 \leq 0,05$, maka Ha diterima dan Ho ditolak, yang berarti secara persial variabel biaya operasional terhadapa pendapatan operasional berpengaruh negatif dan tidak signifikan terhadap return on asset pada bank konvensional yang listing di Bursa Efek Indonesia. Semakin besar nilai BOPO akan menurunkan tingkat profitabilitas bank konvensional. 
Hasil penelitian sejalan dengan kajian teori yang dikemukakan oleh Hariyani (2010:54) rasio BOPO (biaya opersional terhadap pendapatan operasional) atau disebut rasio efisiensi ini digunakan untuk mengukur kemampuan managemen bank dalam mengendalikan biaya operasional terhadapa pendapatan operasional. Semakin kecil rasio ini, berarti semakin efisien biaya operasional yang dikeluarkan bank, sehingga kondisi bermasalah bank semakin kecil.

Hasil hipotesis penelitian menyatakan BOPO berpengaruh negatif dan signifikan terhadap ROA. Hipotesis mendukung penelitian sebelumnya yang dilakukan oleh Eng (2013) menunjukkan hasil bahwa BOPO berpengaruh negatif terhadap Return On Asset (ROA). Persamaan hasil penelitian dikrenakan jumlah sampel yang digunakan relatif sama, sampel peneliti sebanya 9 bank sedangkan sampel Eng sebanyak 7 bank.

\section{Pengaruh non performing loan terhadap return on asset}

Penelitian yang dilakukan menunjuakan, bahwa nilai koefisien variabel non performing loan sebesar 0,187 dengan arah positif dan hasil pengujian hipotesis telah membuktikan pengaruh non performing loan terhadap return on asset memiliki nilai $t$ hitung 2,689 $\geq 1,683$ dan signifikan $0,010 \leq 0,05$, maka Ha diterima dan Ho ditolak, yang berarti secara persial variabel non performing loan berpengaruh positif dan signifikan terhadap return on asset pada bank konvensional yang listing di Bursa Efek Indonesia. Dapat disimpulkan semakin besar NPL akan meningkatkan tingkat profitabilitas bank.

Hasil penelitian tidak sejalan dengan dengan kajian teori yang dikemukakan oleh Hariyani (2010:53) rasio NPL (Non Peformoing Loan) atau rasio kredit bermasalah. Rasio ini menunjukan kemampuan manajemen bank dalam menengelola kredit bermasalah yang diberikan oleh bank. Semakin tinggi rasio ini maka akan semakin buruk kualitas kredit kredit sehingga kondisi bermasalah bank semakin tinggi.

Hasil hipotesis penelitian menyatakan NPL berpengaruh positif dan signifikan terhadap ROA. Hipotesis tidak mendukung penelitian yang dilakukan oleh Aini (2013) menunjukan pengaruh negatif Non Performing Loan (NPL) terhadap Return On Asset (ROA). Perbedaan penelitian dikarenak periode dan sampel yang digunkan. Periode penelitian peneliti selama 5 tahun 2010-2014 sedangkan periode penelitian Aini selam 3 tahun 2009-2011 dan smapel yang digunakan peneliti sebanyak 9 bank sedangkan Aini 61 perusahaan perbankkan. Dilihat dari nilai $\mathrm{R}$ squere peneliti menujuka sebesar $64 \%$ variabel bebas mempengaruhi variabel terikat sedang penelitian Aini 26\% variabel bebas mempengaruhi variabel terikat dan dapat dijelaskan hasil peneliti lebih akuran dari peneliti sebelumnya.

\section{Pengaruh net interest margin terhadap return on asset}

Penelitian yang dilakukan menunjukkan, bahwa nilai koefisien variabel net interest margin sebesar 0,036 dengan arah positif dan hasil pengujian hipotesis telah membuktikan pengaruh net interest margin terhadap return on asset memiliki nilai $t_{\text {hitung }} 3,192 \geq 1,683$ dan signifikan $0,003 \leq 0,05$, maka Ha diterima dan Ho ditolak, yang berarti secara persial variabel net interest margin berpengaruh positf dan signifikan terhadap return on asset padsa bank konvensional yanng listing di Bursa Efek Indonesia. Dapat disimpulkan semakin besar nilai NIM akan meningkat tingkat profitabilitas bank.

Hasil penelitian sejalan dengan kajian teori yang dikemukakan oleh Hariyani (2010:54) Net Interest Margin (NIM) merupakan rasio untuk mengukur kemampuan manajemen bank dalam 
mengelola aktiva produktif untuk menghasilkan pendapatan bunga bersih. Pendapatan bungan bersih diperoleh dari pendapatan bungan dikurangi pendapatan bunga. Semakin tinggi rasio ini maka meningkatkan pendapatan bungan atas aktiva produktif yang dikelola bank kemungkinan kondisi bermasalah bank semakin kecil.

Hasil hipotesi penelitian menyatakan NIM berpengaruh positif dan signifikan terhadap ROA. Hipotesis mendukung penelitian sebelumnya yang dilakukan oleh Aini (2013) menunjukkan hasil bahwa Net Income Margin (NIM) berpengaruh positif terhadap Return On Asset (ROA). Persamaan hasil penelitian dikarenakan smapel yang digunakan sama yaitu bank yang terdaftar di BEI namun hasil penelitian lebih akuran peneliti karena nilia $\mathrm{R}$ squere lebih tinggi dari pada peneliti sebelumnya yaitu $64 \%$ sedang peneleti terdahulu $20 \%$.

\section{Pengaruh loan to deposit ratio terhadap return on asset}

Penelitian yang dilakukan menunjukkan, bahwa nilai koefisien variabel loan to deposit ratio sebesar -0,028 dengan arah negatif dan hasil pengujian hipotesis telah membuktikan pengaruh loan to deposit ratio terhadap return on asset memiliki nilai $\mathrm{t}$ hitung $-2,256 \geq-1,683$ dan signifikan $0,030 \leq 0,05$, maka Ha diterima dan Ho ditolak, yang berarti secara persial variabel loan to deposit ratio berpengaruh negatif dan signifikan terhadap return on asset pada bank konvensional yang listing di Bursa Efek Indonesia. Dapat disimpulkan semakin besar nilai LDR akan menurut tingkat profitabilitas bank.

Hasil penelitian sejalan dengan kajian teori yang dikemukakan oleh Hariyani (2010:55) LDR (Loan To Deposit Ratio) atau rasio kredit terhadap deposito/simpanan. Rasio ini digunakan untuk menilai likuiditas suatu bank dengan cara membagi jumlah kredit yang diberikan oleh bank terhadap dana pihak ketiga. Semakin tinggi rasio ini, semakin rendahnya kemampuan likuiditas bank yang bersangkutan sehingga memungkinkan suatu bank dalam kondisi bermasalah akan semakin besar.

Hasil hipotesis penelitian menyatakan LDR berpengaruh negatif dan signifikan terhadap ROA. Hipotesi mendukung penelitian sebelumnya yang dilakukan oleh Nyoman dan Erni (2015) memperlihatkan hasil bahwa Loan Deposit Ratio (LDR) berpengaruh positif dan signifikan terhadap Return On Asset (ROA). Perbedaan hasil penelitian diindefikasikasi periode penelitian berbeda, peneliti periode 2010-2013 dan peneliti sebelumnya 2009-2013. Dilihat dari objek peneliti menggunkan semua bank konvesional sedangkan peneliti sebelumnya menggukan bank BUSN devisa dan BUSN non devisa.

\section{KESIMPULAN}

Penelitian ini dilakukan untuk menguji dan menganilis pengaruh capital adequacy ratio, biaya operasional terhadapa pendapatan operasional, non performing loan, net interest margin dan loan to deposit ratio terhadap return on asset secara persial. Jumlah sampel yang digunakan dalam penelitian ini sebanyak 9 bank konvensional yang listing di Bursa Efek Indonesia periode 2010-2014. Berdasarkan hasil anlisis data yang telah dilakukan peneliti, maka dapat ditarik kesimpulan sebagai berikut: 1) Hasil pengujian hipotesis telah membuktikan tidak terdapat pengaruh positif signifikan capital adequacy ratio terhadap return on asset secara persial. Hal ini berarti semakin tinggi capital adequacy ratio yang dimiliki bank konvesional maka akan menurunkan nilai return on asset. 2) Hasil pengujian hipotesis telah membuktikan terdapat pengaruh negatif signifikan biaya operasional pada pendapatan operasional terhadap return on asset secara persial. Hal ini berarti semakin tinggi 
biaya operasional terhadapa pendapatan operasional yang dimiliki bank konvesional maka akan menurunkan nilai return on asset. 3) Hasil pengujian hipotesis telah membuktikan terdapat pengaruh positif signifikan non performing loan terhadap return on asset secara persial. Hal ini berarti semakin tinggi non performing loan yang dimiliki bank konvesional maka akan meningkatkan nilai return on asset. 4) Hasil pengujian hipotesis telah membuktikan terdapat pengaruh positif signifikan net interest margin terhadap return on asset secara persial. Hal ini berarti semakin tinggi net interest margin yang dimiliki bank konvesional maka akan menurunkan nilai return on asset. 5) Hasil pengujian hipotesis telah membuktikan tidak terdapat pengaruh positif signifikan loan to deposit ratio terhadap return on asset secara persial. Hal ini berarti semakin tinggi loan to deposit ratio yang dimiliki bank konvesional maka akan menurunkan nilai return on asset.

Investor perlu memperhatikan LDR. LDR merupakan kemampuan bank membayar kewajibannya dalam jangka pendek. Dari hasil penelitian rasio LDR berpengaruh negatif dan tingkan kemampuan bank membayar kewajibannya sebasar 76\%. Bank konvesional yang listing di Bursa Efek Indonesia perlu meninjau kembali nilai CAR. Nilai CAR yang tinggi dapat mengurangi kemampuan bank untuk melakukan ekspantasi karena terlalu fokus untuk mengcover ATMR bank dan akan mempengaruhi kinerja bank dalam meningkatkan profitabilitas. Penelitian ini dapat dijadikan refrensi dan media pertimbangan dalam melakukan penelitian pada objek yang sama yaitu bank konvesional yang listed di Bursa Efek Indonesia, dikarenakan nilai $\mathrm{R}$ square 0,64. Nilai tersebut menenjukan bahwa variabel bebas mempenagruhi varibel terikat sebesar $64 \%$ dan sisanya sebesar $36 \%$ dipengaruhi faktor lain. Nilai 36\% dapat menentukan bahwa ada variabel lain yang dapat mempengaruhi profitabilitas bank seperti inflasi, kurs dan kebijakan pemerintah. Penelitian hanya menggunakan bank konvesional yang terdaftar di Bursa Efek Indonesia dan variabel yang digunakan terbatas pada rasio keuangan saja yaitu rasio CAR, BOPO, NPL, NIM,LDR dan ROA tanpa mempertimbangkan inflasi, kurs dan kebijakan pemerintah.

\section{DAFTAR PUSTAKA}

Ahmad Buyung Nusantara. 2009. Analisis Pengaruh NPL, CAR, LDR dan BOPO Terhadap Profitabilitas Bank (Perbandingan Bank Umum Go Publikdan Bank Umum Non Go Publik di Indonesia PeriodeTahun 2005-2007). Laporan tidak dipublikasikan Universitas Dipenegoro; Semarang.

Almilia dan Herdiningtyas. 2005. Analisis Rasio CAMEL Terhadap Prediksi Kondisi Bermasalah Pada Lembaga Perbankan Periode 2000-2002. Jurnal Akuntansi dan Keuangan Vol. 7 No.2 November 2005.

Brigham, Eugene dan Joel F. Houston. 2006. Dasar- Dasar Manajemen Keuangan. Salemba Emapat; Jakarta.

Dessy, Hutajulu. 2007. Manajemen Investasi. Salemba Empat. Jakarta.

Dwilestari. 2014. AnalisisPengaruhRasio CAR, BOPO, Dan LDR Terhadap Kinerja Keuangan Perbankan Yang Terdaftar Di Bursa Efek Indonesia Tahun 2008-2012. Laporan tidak dipublikasikan Universitas Muhammadiyah; Surakarta.

Farah Margaretha dan Narsheilly Pingkai Zai. 2013. Faktor-Faktor Yang Mempengaruhi Kinerja Keuangan Perbankkan Indonesia. Jurnal bisnis dan akuntansi. Vol. 15, No 2, Desember 2013, Hlm. 133-144

Fitriani Prastiyaningtyas. 2010. Faktor- Faktor Yang Memepengaruhi Profitabilitas Perbankkan (studi kasus bank umum go public yang listed di BEI tahun 2005-2008). Laporan tidak dipublikasikan Universitas Dipenegoro; Semarang. 
Gandapradja, Permadi. 2004. Dasar dan Prinsip Pengawasan Bank. Gramedia Pustaka Utama: Jakarta.

Ghozali, Imam. 2009. Ekonemetrika. BP-UNDIP: Semarang.

Gujarati, Damodar. 2003. Ekonemetrika Dasar. Erlangga; Jakarta.

Harahap, Sofyan S. 2007. Analisis Kritis atas Laporan Keuangan. Edisi Kesatu. PT. Raja Grafindo Persada. Jakarta.

Hariyani, Iswi. 2010. Restrukturisasi dan Penghapusan Kredit Macet. Kompas Gramedia: Jakarta.

Kasmir. 2012. Bank dan Lembaga Keuangan Lainnya. Edisi revisi cet. 11.Rajawali Pers; Jakarta.

Mamduh, M. Hanafi. 2003. Analisa Laporan Keuangan. UPP MPP YKPN. Yogyakarta.

Margaretha, Farah. 2005. Manajemen Keuangan Bagi Industri Jasa. Grasindo: Jakarta.

Marlupi Nanda Permata Sari. 2006. Analisa Kinerja Perbankkan Dengan Menggunkan Metode CAMEL (studi pada BEI periode 2002-2004). Laporan tidak dipublikasikan Universitas Brawijaya; Malang.

Melissa Rizky. 2012. Analisa Kinerja Keuangan Dengan Metode CAMELS (studi kasuk pada PT. Bank Sulselbar 2008-2010). Laporan tidak dipublikasikani Universitas Hasanudid; Makasar.

Nur Aini. 2013. Pengaruh CAR, NIM, LDR, NPL, BOPO, dan Kualitas Aktiva Produktif Terhadap Perubahan Laba (studi empiris pada perusahaan perbankan yang terdaftar di BEI) Tahun 2009-2011. Dinamika Akuntansi, Keuangan dan Perbankan, Mei 2013, Hal: $14-25$, Vol. 2, No. 1

Nurani. 2012. Analisis Pengaruh Capital Adequacy Ratio (CAR), Efisiensi (BOPO), Non Performing Loan (NPL) Dan Loan To Deposit Ratio (LDR) Terhadap Return On Assets (ROA) (studi pada bank persero pemerintah). Laporan tidak dipublikasikan Universitas Hasanuddin; Makassar.

Nyoman Trisna Herawati dan Luh Gede Erni Sulindawati. 2015. Analisi Pengaruh NIM, BOPO, LDR, dan NPL TerhadapProfitabilitas. Jurnal S1 Ak. Universitas Pendidikan Ganesa. Volume: 3 No. 1 Desember 2015.

Samsul, Muhammad. 2006. Pasar Modal dan Manajemen Portofolio. Erlangga. Jakarta

Santoso, Agus. 2001. Manajemen Keuanagan Teori Dan Aplikasi. BPFE; Yogyakarta

Slamet Riyadi dan Agus Yulianto. 2014. Pengaruh Pembiayaan Bagi Hasil, Pembiayaan Jual Beli, Financing To Deposit Ratio (FDR) dan Non Performing Financing (NPF) Terhadap Profitabilitas Bank Umum Syariah Di Indonesia. Accounting Analysis Journal, AAJ (4) (2014).

Tan Sau Eng. 2013. Pengaruh NIM, LDR, NPL \& CAR Terhadap ROA Bank Internasional dan Bank Nasional Go Public Periode 2007-2011. Jurnal Dinamika Manajemen Vol. 1 No.3 Juli - September 2013.

Tandelilin, Eduardus. 2001. Pengaruh Investasi dan Manajemen Portofolio; BPFE UGM Yogyakarta.

Westo, J.F dan Thomas E.C. 2010. Manajemen Keuangan. Edisi revisi jilid 1. Binarupa Aksara publisher. Tanggerang.

www.bi.go.id

www.IDX.com

www.OJK.go.id 